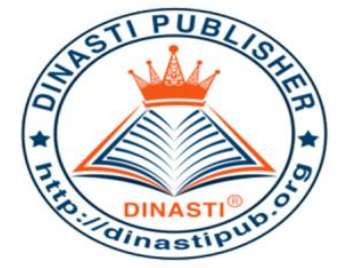

\title{
ANALYSIS OF EFFECT OF CAPR, DAR, ROA AND SIZE ON TAX AVOIDANCE
}

\section{Adil Akbar ${ }^{1}$, Hakiman Thamrin ${ }^{2}$}

${ }^{1)}$ Mercu Buana University, Jakarta, Indonesia

${ }^{2)}$ Mercu Buana University, Jakarta, Indonesia

ARTICLE INFORMATION

Received: $29^{\text {th }}$ March 2020

Revised: $15^{\text {th }}$ April 2020

Issued: $6^{\text {th }}$ May 2020

Corresponding author: firs author E-mail:

adilakbar1992@gmail.com

hakiman.thamrin@mercubuana.ac.id

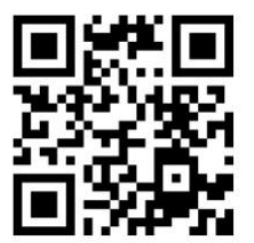

DOI:10.31933/DIJMS
Abstract: This study aimed to identify the effect of the independent variable capital intensity (CAPR), return on assets (ROA), debt to asset ratio (DAR), and the size of the company (SIZE) on tax avoidance (CETR) as dependent variable. This study tested using multiple linear regression analysis with the SPSS 25 program with a causality and comparative approach using cross sectional data. The results of the study in 2015 showed that the capital intensity and debt to asset ratio does not affect on tax avoidance, while return on assets and company size have significant negative effect on tax avoidance. In 2017, showed that the capital intensity, debt to asset ratio, and company size does not affect on tax avoidance, while return on assets has a significant negative effect on tax avoidance. Hypothesis testing results indicate that the independent variables simultaneously in 2015 and 2017 affect the dependent variable.

Keywords: Capital Intensity, Return on Assets, Debt to

Asset Ratio, Company Size, Tax Avoidance.

\section{INTRODUCTION}

One of the nation's independence visible manifestation of the progress of national development. Indonesia is one country whose main source of funding comes from tax revenue.

Since the election of Ir. Joko Widodo (Jokowi) as 7th of President of the Republic of Indonesia, national development in infrastructure and property to be one of the featured programs Jokowi administration, such as a million homes program to meet the residential needs of Indonesian society. 
The next phenomenon the government has set Government Regulation No. 34 in 2016, amendments to Government Regulation No. 71 in 2008 concerning the new Final Income Tax rate on income from the transfer of title to land and buildings, and the binding sale and purchase agreement for land and buildings. This regulation shall determine the amount of income tax from the sale of a house or land that is lower than the previous regulation of rates of $5 \%$ to $2.5 \%$ and came into force after 30 days from the date of enactment which falls on September 8, 2016.

Effective tax rate is the percentage of the tax rate to be applied to certain tax bases so that the tax burden more effectively. Broadly, the effective tax rate is a measure of the tax burden on companies that represent the value of taxes paid through the company's revenues (Handayani et.al, 2016).

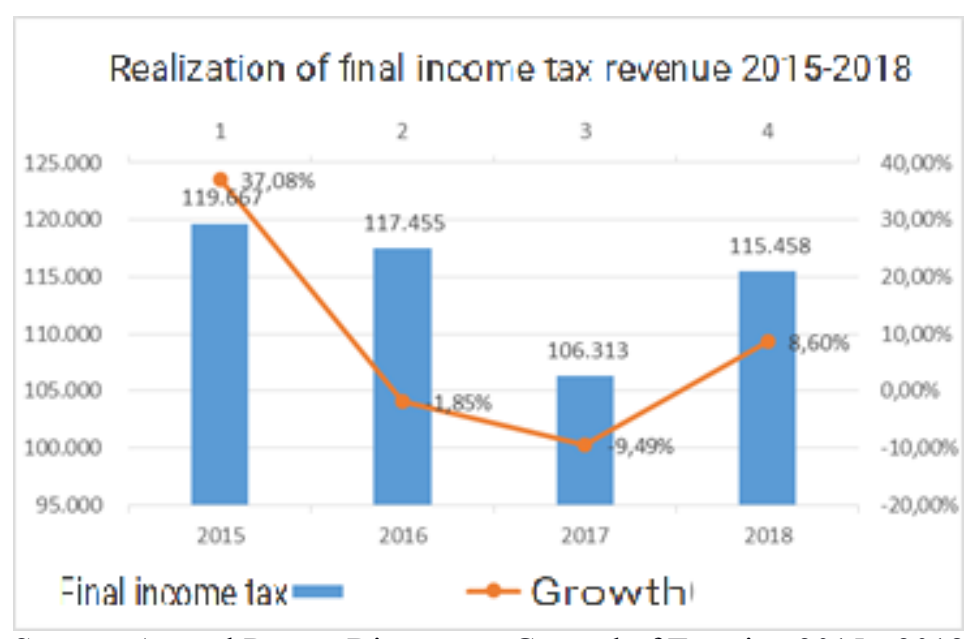

Source: Annual Report Directorate General of Taxation 2015 - 2018

Picture 1. Final Income Tax Revenues 2015-2018

Fiscal Policy Office noted that since 2016, the property sector is sluggish, the realization of tax revenue growth in the construction and property sector fell compared to the prior year period. According to Asep Nurwanda as Division Head of Fiscal Policy Agency, the slowing property sector that have occurred since the last three years due to the drop in commodity prices. So consumers properties that work in the sector affected.

The next phenomenon related to property and real estate sector is originated from machine simulator license driver cases conducted by the DS in 2013, investigators found the presence of tax evasion on property transactions taking place in society. In the court proceedings revealed the existence of a luxury home sales by developers to the defendant. But the notary deed listed the actual prices. The value difference, obviously causes a loss of potential revenue (Tambunan, 2015).

Efforts to tax evasion should be done legally by the taxpayer and not contrary to the provisions of taxation, namely the method of utilizing loopholes in the tax regulations (Gem, 2018). However, the company owner usually will encourage aggressive tax management action to reduce the tax burden arising (Chen et.al in Handayani et.al, 2016). If the successful 
management of tax avoidance efforts, is not likely to have an impact both on the rise in management performance assessment because it has managed to maintain the company's profit, so usually the principal will give awards or bonuses to employees of the company.

\section{LITERATURE REVIEW}

\section{Agency Theory}

Agency theory is a theory of the relationship between the agent and the principal states where one party has more information and one of the other parties have less (Jensen and Meckling in Hand, 2016).

The information imbalance causing asymmetry of information between the principals and the agent. Detailed information may be used by the agent, the agent to commit fraud to stakeholders (Handayani, 2016). The conditions such as agents manipulation of financial statements or tax reports which aim to improve their own welfare.

\section{Capital Intensity}

Capital intensity reflects how much capital the company needed to generate the revenue earned from the decrease or increase of fixed assets. Capital intensity is defined as the ratio of fixed assets such as equipment, machinery and property of the total assets of the company (Noor et al. In Puspita \& Febriyanti, 2017).

\section{Return on Assets}

ROA is a formula to measure process management capabilities, especially its fixed assets in maximizing profitability and overall managerial efficiency (Slamet in Mulyani et al., 2017).

\section{Debt to Asset Ratio}

DAR is the ratio used to measure the extent of the company's assets are financed by debt. This means that in terms of taxation, high and low corporate debt will affect the company's tax burden.

\section{Size of Company}

The size of the company in a tax evasion can be measured by the natural logarithm of the total assets, because the large size of the company which usually have high resources, it is possible to have an influence on tax evasion.

\section{Framework}

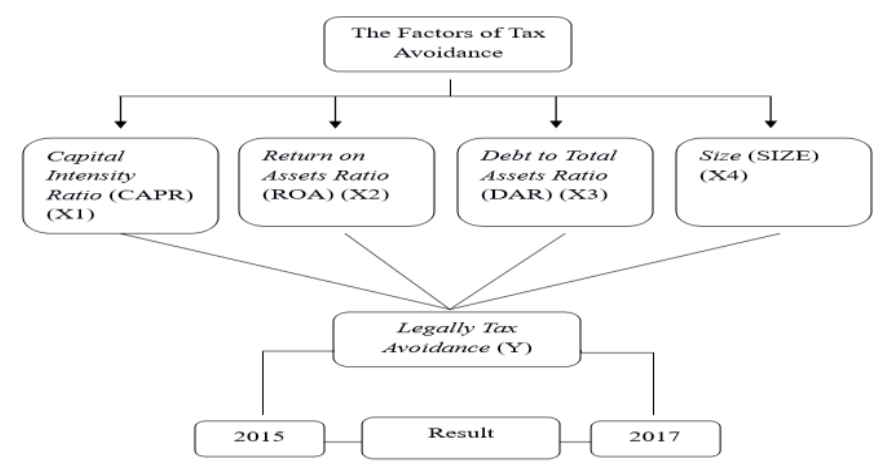

Source: Data processed by author (2019)

Picture 2. Thinking Framework 


\section{RESEARCH METHODS \\ Research Design}

This type of research is quantitative research with causality and comparative approach using a cross sectional. The research data are secondary data on the company's financial statements and the real estate sector of the properties listed on the Indonesia Stock Exchange (IDX) in 2015 and 2017.

The study population was recorded as many as 63 companies of real estate and properties listed on the Indonesia Stock Exchange (IDX) until November 2019. The research sample was taken in 2015 before the entry into force of Government Regulation No.34 in 2016 and in 2017 after the enactment of Government Regulation No.34 in 2016.

The research sample was selected a total of 29 real estate companies and properties determined by purposive sampling method. The data analysis method uses quantitative data with ratio scale measurement. The research sample data were analyzed by inferential analysis through multiple linear regression tests using the SPSS 25 program.

\section{Dependent Variables}

Tax avoidance (CETR)

$$
\text { CETR } \mid=\frac{\text { Tax expense }}{\text { Earnings Before Tax }}
$$

\section{Independent Variables}

Capital intensity (CAPR)

$$
\begin{array}{r|l}
\text { CAPR } & =\frac{\text { Total fixed assets }}{\text { Total assets }} \\
\text { ROA } & =\frac{\text { Earnings after tax }}{\text { Total assets }} \\
\text { Return on assets (ROA) } & \\
\text { Debt to assets ratio (DAR) } & \text { Firm size (SIZE) } \\
\text { DAR } & =\frac{\text { Total amount of døbt }}{\text { Tize }}=\frac{\text { Ln (Total aset) }}{\text { Siz }}
\end{array}
$$

\section{FINDINGS AND DISCUSSION}

\section{Descriptive Analysis}

Table 1. Descriptive Statistics Variable CAPR

\begin{tabular}{ccccccc}
\hline & & N & Minimum & maximum & mean & Std. deviation \\
\hline 2015 & CAPR & 29 &, 00 &, 40 &, 0721 &, 08756 \\
\hline 2017 & CAPR & 29 &, 00 &, 45 &, 0679 &, 09163 \\
\hline \multicolumn{2}{l}{ Source: Output SPSS 25 (2019) }
\end{tabular}

According to the table 1 the minimum value CAPR ratio in 2015 and 2017 amounting to 0.00. This means that these companies have not been able to optimize on the amount of capital to increase its profit through its fixed assets. Then the maximum value of a sample of 
the CAPR ratio in 2015 and 2017 of 0.40 and 0.45 which means that the company is able to process the amount of capital to help optimize revenue through its fixed assets approximately $40 \%-45 \%$.

Table 2. Descriptive Statistics Variable ROA

\begin{tabular}{|c|c|c|c|c|c|c|}
\hline & & $\mathbf{N}$ & Minimum & maximum & mean & Std. deviation \\
\hline 2015 & $\mathrm{ROA}$ & 29 &, 00 &, 27 &, 0648 &, 06214 \\
\hline 2017 & $\overline{\mathrm{ROA}}$ & 29 &, 00 & 27 & 0493 & 04276 \\
\hline
\end{tabular}

Based on Table 2, the minimum value of ROA ratio of 0.00 in 2015 and 2017. This means that the company is not able to manage their assets to increase its profit. Then note the maximum value of a sample of ROA in 2015 and 2017 by 0.27 and 0.17 which means that there are companies that try to manage their assets in order to optimize revenue.

Table 3. Descriptive Statistics Variable DAR

\begin{tabular}{|c|c|c|c|c|c|c|}
\hline & & $\mathbf{N}$ & Minimum & maximum & mean & Std. deviation \\
\hline 2015 & DAR & 29 &, 08 &, 65 &, 4224 &, 14887 \\
\hline 2017 & DAR & 29 & 07 & 79 & 4000 & 16803 \\
\hline
\end{tabular}

Based on Table 3, the minimum value of the DAR ratio of 0.08 in 2015 and 2017 by 0.07. This means the company does not much depend on debt to manage its assets for 2015 and 2017 the company's assets are financed by debt is only about 7\% and $8 \%$ of total assets, so that the company is unable to repay its obligations. Then note the maximum value of a sample of the DAR ratio in 2015 and 2017 amounted to 0.65 and 0.79 which means that the company is relying on half of its assets financed by debt, so it is feared such company is not able to repay long-term liabilities in the future.

Table 4. Results Descriptive Statistics Variable SIZE

\begin{tabular}{|c|c|c|c|c|c|c|}
\hline & & $\mathbf{N}$ & Minimum & maximum & mean & Std. deviation \\
\hline 2015 & SIZE & 29 & 25,89 & 31,35 & 29,42 & 1,32786 \\
\hline 2017 & SIZE & 29 & 25,91 & 31,67 & 29,42 & 1,37049 \\
\hline
\end{tabular}

Based on Table 4, the minimum value SIZE ratio of 25.89 in 2015 and 2017 amounted to 25.91 Starter owned by Bekasi Asri Pemula Tbk, this ratio is obtained from the natura logarithm calculation ( $\mathrm{Ln}$ ) of the total assets of a company, which means the company has a total most asset lower than other companies so that they can be categorized Bekasi Asri Pemula Tbk is a company with the size of the lowest in the sample in 2015 and 2017. 
Then the maximum SIZE ratio in 2015 and 2017 amounted to 31.35 and 31.67 can be considered as a large company size as measured by total assets is high, the company in 2015 and 2017 is Lippo Karawaci Tbk.

Table 5. Results Descriptive Statistics Variable CETR

\begin{tabular}{ccccccc}
\hline & & N & Minimum & maximum & Mean & Std. deviation \\
\hline 2015 & SIZE & 29 &, 01 &, 75 &, 2528 &, 16897 \\
\hline 2017 & SIZE & 29 &, 03 &, 75 &, 2286 &, 16383 \\
\hline \multicolumn{7}{l}{ Source: Output SPSS 25(2019) }
\end{tabular}

Based on Table 5, the minimum value CETR ratio of 0.01 in 2015 and 2017 of 0.03 owned by Greenwood Sejahtera Tbk. This means that the company is descriptive, not actively seeking to legality tax avoidance is indicated by a ratio value close to 0 .

Then note the maximum value of a sample of CETR ratio between 2015 and 2017 of 0.75 which means that the company is actively seeking to legality tax avoidance in the management of managing the business.

\section{The Results of $t$-Test}

Table 6. Results of t-Test (Partial Test) Samples 2015

\begin{tabular}{|c|c|c|c|c|c|c|}
\hline \multicolumn{7}{|c|}{ Coefficients } \\
\hline & & $\begin{array}{r}\mathrm{Co} \\
\text { unst }\end{array}$ & $\begin{array}{l}\text { cients } \\
\text { ardized }\end{array}$ & $\begin{array}{l}\text { standardized } \\
\text { Coefficients }\end{array}$ & & \\
\hline \multicolumn{2}{|c|}{ Model } & $\mathrm{B}$ & Std. Error & beta & $\mathrm{t}$ & Sig. \\
\hline \multirow[t]{5}{*}{1} & (Constant) & 1,967 &, 487 & & 4,037 &, 000 \\
\hline & CAPR & 237 & 267 &, 123 &, 885 & 385 \\
\hline & ROA & -1.936 &, 378 &,- 712 & -5.125 &, 000 \\
\hline & $\overline{\mathrm{DAR}}$ &,- 075 &, 163 &,- 066 &,- 461 & 649 \\
\hline & SIZE &,- 054 &, 017 &,- 423 & -3.136 &, 004 \\
\hline \multicolumn{7}{|c|}{ a. Dependent Variable: CETR } \\
\hline
\end{tabular}

From Table 6 above, the interpretation of the results obtained sample of 2015 research hypothesis that each of the variables that will be described as follows:

a. Capital intensity (CAPR)

H0: There is no effect of Capital Intensity on Legally Tax Avoidance on real estate and property companies listed on the IDX in the year prior to the enactment of Government Regulation No.34 in 2016.

H1: There is effect of Capital Intensity on Legally Tax Avoidance on real estate and property companies listed on the IDX in the year prior to the enactment of Government Regulation No.34 in 2016.

The $\mathrm{t}$-test results for $\mathrm{H} 1$ known that the value of sig CAPR is 0.385 , greater than the probability value of 0.05 , or the value of $0.385>0.05$, then $\mathrm{H} 1$ is rejected and $\mathrm{H} 0$ is accepted. The CAPR variable has a $t$-count of 0.885 with a $t$-table of 2.064 . So $t$-count $<\mathrm{t}$-table which 
means that the CAPR variable has no contribution to CETR, so it can be concluded that capital intensity has no effect on legally tax avoidance in the year prior to the enactment of Government Regulation No.34 in 2016.

b. Return on assets (ROA)

H0: There is no effect of ROA on Legally Tax Avoidance on real estate and property companies listed on the IDX in the year prior to the enactment of Government Regulation No.34 in 2016.

H2: There is effect of ROA on Legally Tax Avoidance on real estate and property companies listed on the IDX in the year prior to the enactment of Government Regulation No.34 in 2016.

The t-test results for $\mathrm{H} 2$ note that the value of sig ROA is 0,000 , smaller than the probability value of 0.05 , or the value of $0,000<0.05$, then $\mathrm{H} 2$ is accepted and $\mathrm{H} 0$ is rejected. The ROA variable has a t-test of 5.125 and $t$-table of 2.064. So t-count $>t$-table indicates the ROA variable has a contribution to CETR. A negative $t$ value illustrates that ROA has an inverse relationship with CETR. So it can be concluded that ROA has a significant negative effect on legally tax avoidance in the year before the enactment of Government Regulation No.34 in 2016.

c. Debt to Asset Ratio (DAR)

H0: There is no effect of DAR on Legally Tax Avoidance on real estate and property companies listed on the IDX in the year prior to the enactment of Government Regulation No.34 in 2016.

H3: There is effect of ROA on Legally Tax Avoidance on real estate and property companies listed on the IDX in the year prior to the enactment of Government Regulation No.34 in 2016.

The results of the t-test for known H3 sig DAR value is 0.649, larger than the probability value of 0.05 , or a value $0.649>0.05, \mathrm{H} 0$ is accepted. The DAR variable has a ttest of 0.461 and the t-table is 2.064 . t-count $<\mathrm{t}$-table can be interpreted that the DAR variable has no contribution to CETR. A negative $t$ values illustrates that the DAR has a relationship opposite to CETR. So it can be concluded that the DAR variable has no effect on legally tax avoidance in the year before the enactment of Government Regulation No.34 in 2016.

d. Company size (SIZE)

H0: $\quad$ There is no effect of SIZE variable on the Legally Tax Avoidance in real estate and property company listed on the IDX in the year before the entry into force of Regulation No.34 of 2016.

H4: There is effect of SIZE variable on the Legally Tax Avoidance in real estate and property company listed on the IDX in the year before the entry into force of Regulation No.34 of 2016.

The $\mathrm{t}$-test results for $\mathrm{H} 4$ revealed that the SIZE sig value was 0.004 , smaller than the 0.05 probability value, or 0.004 value 0.05 , then $\mathrm{H} 4 \mathrm{H} 0$ was rejected. SIZE variable has a t-test of 3.136 and t-table is 2.064. t-test $>$ t-table indicates the SIZE variable has a contribution to CETR. A negative $t$ value illustrates that SIZE has an inverse relationship with CETR. So it 
can be concluded that SIZE has a significant negative effect of legally tax avoidance in the year prior to the enactment of Government Regulation No.34 in 2016.

Table 7. Results of t-Test (Partial Test) Samples 2017

\section{Coefficients}

\begin{tabular}{|c|c|c|c|c|c|c|}
\hline \multirow{2}{*}{\multicolumn{2}{|c|}{ Model }} & \multicolumn{2}{|c|}{$\begin{array}{c}\text { Coefficients } \\
\text { unstandardized }\end{array}$} & \multirow{2}{*}{$\begin{array}{c}\text { standardized } \\
\text { Coefficients } \\
\text { beta }\end{array}$} & \multirow[b]{2}{*}{$\mathrm{t}$} & \multirow[b]{2}{*}{ Sig. } \\
\hline & & $\mathrm{B}$ & Std. Error & & & \\
\hline 1 & (Constant) &, 614 &, 601 & & 1,023 &, 317 \\
\hline & CAPR &, 630 &, 340 &, 352 & 1,852 &, 076 \\
\hline & ROA & -2.518 &, 719 &,- 657 & -3.502 &, 002 \\
\hline & DAR &,- 014 &, 172 &,- 014 &,- 080 &, 937 \\
\hline & SIZE &,- 010 &, 021 &,- 085 &,- 482 &, 634 \\
\hline
\end{tabular}

a. Dependent Variable: CETR

Source: Adapted researchers (2019)

From table 7 above, the result of interpretation of the research hypothesis that each of the variables that will be described as follows:

a. Capital intensity (CAPR)

H0: There is no effect of Capital Intensity on Legally Tax Avoidance on real estate and property companies listed on the IDX in the year after to the enactment of Government Regulation No.34 in 2016.

H1: There is effect of Capital Intensity on Legally Tax Avoidance on real estate and property companies listed on the IDX in the year after to the enactment of Government Regulation No.34 in 2016.

The t-test results for H1 known that the CAPR sig value is 0.076 , greater than the probability value of 0.05 , or a value of $0.076>0.05$, then $\mathrm{H} 1$ is rejected and $\mathrm{H} 0$ is accepted. The CAPR variable has a $t$-count of 1.852 with a t-table of 2.064 . So $t$-count $<t$-table can be interpreted that the CAPR variable has no contribution to CETR, so it can be concluded that capital intensity has no effect on legally tax avoidance in the year after the enactment of Government Regulation No.34 in 2016.

b. Return on Assets (ROA)

H0: There is no effect of ROA on Legally Tax Avoidance on real estate and property companies listed on the IDX in the year after to the enactment of Government Regulation No.34 in 2016.

H2: $\quad$ There is effect of ROA on Legally Tax Avoidance on real estate and property companies listed on the IDX in the year after to the enactment of Government Regulation No.34 in 2016.

The t-test results for $\mathrm{H} 2$ known that the ROA sig value is 0.002 , smaller than the probability value of 0.05 , or the value of $0.002<0.05$, then $\mathrm{H} 2$ is accepted and $\mathrm{H} 0$ is rejected. The ROA variable has a t-count is 3.502 and $t$-table is 2.064 . So $t$-count $>t$-table can mean the ROA variable has a contribution to CETR. A negative $t$ value illustrates that ROA has an inverse relationship with CETR. So it can be concluded that ROA has a significant negative 
effect on legally tax avoidance in the year after the enactment of Government Regulation No.34 in 2016.

c. Debt to Asset Ratio (DAR)

H0: There is no effect of DAR on Legally Tax Avoidance on real estate and property companies listed on the IDX in the year after to the enactment of Government Regulation No.34 in 2016.

H3: There is effect of DAR on Legally Tax Avoidance on real estate and property companies listed on the IDX in the year after to the enactment of Government Regulation No.34 in 2016.

The t-test results for $\mathrm{H} 3$ known that the DAR sig value was 0.937 , greater than the probability value of 0.05 , or the value of $0.937>0.05$, then $\mathrm{H} 3$ was rejected and $\mathrm{H} 0$ was accepted. The DAR variable has a t-count of 0.080 and a t-table of 2.064. So t-count $<\mathrm{t}$-table indicates the DAR variable has no contribution to CETR. A negative $t$ value illustrates that DAR has an inverse relationship with CETR. So it can be concluded that DAR has no effect on legally tax avoidance in the year after the enactment of Government Regulation No.34 of 2016.

d. Company size (SIZE)

H0: There is no effect of SIZE on Legally Tax Avoidance on real estate and property companies listed on the IDX in the year after to the enactment of Government Regulation No.34 in 2016.

H4: There is effect of SIZE on Legally Tax Avoidance on real estate and property companies listed on the IDX in the year after to the enactment of Government Regulation No.34 in 2016.

The t-test results for H4 known SIZE sig value is 0.634 , greater than the probability value of 0.05 , or a value of $0.634>0.05$, then $\mathrm{H} 4$ is rejected and $\mathrm{H} 0$ is accepted. The SIZE variable has a t-count of 0.482 and a $t$-table of 2.064. So t-count $<\mathrm{t}$-table means that the SIZE variable has no contribution to CETR. A negative $t$ value illustrates that SIZE has an inverse relationship with CETR. So it can be concluded that SIZE has no effect on legally tax avoidance in the year after the enactment of Government Regulation No.34 in 2016.

\section{Discussion of The Results of t-Test Analysis}

a. Effect of capital intensity (CAPR) to legally tax avoidance

T-test results in the year before and after the enactment of Government Regulation No.34 in 2016, showed the similarity that both conditions equally showed there was no influence between capital intensity on legally tax avoidance. This is due, the average amount of capital to support income in real estate property companies in the 2015 and 2017 samples is only around $6 \%$ to $7 \%$. Most assets owned by real estate and property companies are assets to be resold. So the cost of depreciation of fixed assets in companies contained in this study sample, is not intended to make tax avoidance efforts, but only more solely companies running company operations. 


\section{b. Influence Return on Assets (ROA) of Legally Tax Avoidance}

T-test results in the year before and after the enactment of Government Regulation No.34 in 2016, showed the similarity that both situations, there were both significant negative effects and ROA variables on legally tax avoidance. In other words, the higher the ROA the lower the legally tax avoidance effort. Because real estate and property companies are now the corporate sector that is contributing to the implementation of the million house program in the Joko Widodo Era of Government, to attract public interest in the program, there are certainly many government policies that are devoted to supporting the efforts of real estate and property sector companies in marketing units its units to the public. The bank interest installment policy and/or low tax rates are expected to keep the company able to maintain profits. But profitable for from the real estate and property sector will certainly be a tight supervision of the government, especially in terms of tax supervision and auditing so as to encourage Taxpayers to prefer to obey the applicable tax provisions.

c. Effect of Debt On Asset (DAR) to Legally Tax Avoidance

T-test results in the year before and after the enactment of Government Regulation No.34 in 2016 showed the similarity that in both conditions, both showed that there was no influence of the DAR variable on legally tax avoidance, which means that the higher or lower the company's debt, would not affect companies to practice legally tax avoidance. This happens because the real estate and property companies on average have large investment property assets, the high debt of the company is not only deliberately done by management only to create a legally tax avoidance effort, although there will be an interest expense due to corporate debt that can be used to reduce the corporate tax burden. However, management will certainly be more conservative in financial statements and be careful in managing financial ratios and cash flow related to company operations, so that the interest expense incurred for legally tax avoidance efforts will not be commensurate with the high risks that companies must face due to having large debts.

d. Influence of company size (SIZE) to Legally Tax Avoidance

T-test results in the year prior to the enactment of Government Regulation No.34 in 2016 showed that there was a significant negative influence and effect on legally tax avoidance, which can be interpreted that the higher the size of the company, the lower the level of effort in the practice of legally tax avoidance. This is certainly reasonable because the SIZE variable is measured using the natural logarithm of the company's total assets. So if the total assets of a company are getting higher, then the company will certainly be closely monitored by the Directorate General of Taxes as the country's efforts to maximize the potential for tax revenue. Therefore, the more size a successful real estate and property company becomes a large company, the fewer companies will dare to practice tax avoidance (legal tax avoidance). Because the size of the company has been already large, the $5 \%$ tariff will not be too heavy a tax burden for the company and management will be more inclined to choose tax compliance rather than bear the potential risk that would be accepted if the practice of tax avoidance. 
Then in the year after the enactment of Government Regulation No.34 in 2016, the tax rate on the transfer of land and buildings was changed to $2.5 \%$ by the Government of the Republic of Indonesia. The results showed there was no influence between company size and legal tax avoidance, which means that tax obligations for both small and large companies no longer make the company's main focus on tax avoidance. This is due to the new tax rate $(2.5 \%)$ which is not too heavy a heavy corporate tax burden even for small company sizes.

\section{Results and Discussion of the F-Test (Simultaneous Test)}

Table 8. Test Results F (Simultaneous Test) Samples 2015

\begin{tabular}{lcccccc}
\hline \multicolumn{7}{c}{ ANOVAa } \\
\hline \multirow{2}{*}{ Model } & $\begin{array}{c}\text { Sum of } \\
\text { Squares }\end{array}$ & df & mean Square & F & Sig. \\
\hline \multirow{2}{*}{1} & Regression &, 488 & 4 &, 122 & 9.380 &, $000 \mathrm{~b}$ \\
\cline { 2 - 7 } & residual &, 312 & 24 &, 013 & & \\
\cline { 2 - 6 } & Total &, 799 & 28 & & & \\
\hline a. Dependent Variable: CETR \\
\hline \multicolumn{2}{l}{ b. Predictors: (Constant), SIZE, ROA, CAPR, DAR } \\
Source: Output SPSS 25 (2019)
\end{tabular}

Ho: There is no simultaneous effect of CAPR, ROA, DAR and SIZE on legally tax avoidance on real estate and property companies listed on the IDX in the year prior to the enactment of Government Regulation No.34 in 2016.

H5: There is a simultaneous effect of CAPR, ROA, DAR and SIZE on legally tax avoidance on real estate and property companies listed on the IDX in the year before the enactment of Government Regulation No.34 in 2016.

The results of table 8 above, it can be seen that the F-test results show that the significance value is 0,000 , smaller than the probability value of 0.05 , or the value of $0,000<$ 0.05 , then $\mathrm{Ha}$ is accepted and $\mathrm{H} 5$ is rejected. Then, strengthened by the F-count result is 9.380 and the F-table is 2.76. So F-count $>$ F-table which is interpreted simultaneously the independent variable has a contribution to the dependent variable. So it can be concluded that the simultaneous CAPR, ROA, DAR, and SIZE significantly affect and positively affect legally tax avoidance in the year before the enactment of Government Regulation No.34 in 2016.

Table 9. Test Results F (Simultaneous Test) Samples 2017

\begin{tabular}{|c|c|c|c|c|c|c|}
\hline \multicolumn{7}{|c|}{ ANOVAa } \\
\hline \multicolumn{2}{|c|}{ Model } & $\begin{array}{c}\text { Sum of } \\
\text { Squares }\end{array}$ & df & mean Square & $\mathbf{F}$ & Sig. \\
\hline \multirow[t]{3}{*}{1} & Regression &, 263 & 4 &, 066 & 3.222 &, $030 \mathrm{~b}$ \\
\hline & residual &, 489 & 24 &, 020 & & \\
\hline & Total &, 752 & 28 & & & \\
\hline \multicolumn{7}{|c|}{ a. Dependent Variable: CETR } \\
\hline \multicolumn{7}{|c|}{ b. Predictors: (Constant), SIZE, ROA, CAPR, DAR } \\
\hline
\end{tabular}


Ho: $\quad$ There is no simultaneous effect of CAPR, ROA, DAR and SIZE on Legally Tax Avoidance on real estate and property companies listed on the IDX in the year after the enactment of Government Regulation No.34 in 2016.

H5: There is a simultaneous effect of CAPR, ROA, DAR and SIZE on Legally Tax Avoidance on real estate and property companies listed on the IDX in the year after the enactment of Government Regulation No.34 in 2016.

The results of table 9 above can be seen that the F-test results revealed that the significance value is 0.030 , smaller than the probability value of 0.05 , or the value of $0.030<$ 0.05 , then $\mathrm{H} 5$ is accepted and Ho is rejected. Then, strengthened by the F-count result is 3.222 and the F-table is 2.76. So F-count $>$ F-table which is interpreted simultaneously the independent variable has a contribution to the dependent variable. So it can be concluded that simultaneously CAPR, ROA, DAR, and SIZE significantly influence and positively affect legally tax avoidance in the year after the enactment of Government Regulation No.34 in 2016.

\section{CONCLUSION AND SUGGESTION}

Based on partial test results of hypothesis testing with multiple regression analysis in 2015 (before the enactment of Government Regulation No.34 in 2016), showed that the capital intensity and debt to asset ratio does not affect on tax avoidance, while return on assets and company size have significant negative effect on tax avoidance. In 2017, showed that the capital intensity, debt to asset ratio, and company size does not affect on tax avoidance, while return on assets has a significant negative effect on tax avoidance. Hypothesis testing results indicate that the independent variables simultaneously in 2015 and 2017 affect the dependent variable.

\section{REFERENCES}

Gem, AD, Nurlaela, S and W, EM. 2018. "Effect of Size, Age, Profitability, Leverage and Sales Growth Against Tax Avoidance". Journal of Accounting and Taxes. Vol.19 (01), pp: 10-20.

Hand, YD and Yumsih, S. 2016. "Expert Power Chief Financial Officer, Chief Financial Officer of Political Power And Characteristics Terhaddap Company Effective Tax Rates". Journal of Business \& Economics. Vol.14 (2), pp: 132-142.

Mulyani, S., Kusmuriyanto \& Suryarini, T. 2017. "Determinant Analysis of Tax Avoidance In Manufacturing Company in Indonesia". Journal RAK (Financial Accounting Research). Vol.2 (3), pp: 53-66.

Pakpahan, Robert. 2015. Annual Report The Directorate General of Taxation 2015. [Online] Available: https://www.pajak.go.id/id/tahunan-page. [December 20, 2019].

Pakpahan, Robert. 2017. Annual Report The Directorate General of Taxation 2017. [Online] Available: https://www.pajak.go.id/id/tahunan-page. [December 20, 2019]. 
Puspita, D. \& Febrianti, M. 2017. "Factors Affecting Tax Avoidance In Manufacturing Company in Indonesia Stock Exchange”. Journal of Business and Accounting. Vol.19 (01), pp: 38-46.

Sukmawijaya, Angga. 2019. Throughout 2018 Tax Revenues Decline Of Property Sector. [Online] Available: https://kumparan.com/@kumparanbisnis/sepanjang-2018-realisasipenerimaan-pajak-dari-sektor-properti-turun-1548303510643494667. [December 20, 2019]

Tambunan, ES. 2015. Tax Problems Behind the rise of Property Business. [Online] Available: https://majalahpajak.net/problematika-pajak-di-balik-maraknya-bisnis-properti/. [December 20, 2019.] 